\title{
Development of Chromatographic Method for Determination of Impurities in Solid Dispersion of Dasatinib
}

\author{
Chandrakant Sojitra' ${ }^{1,2,3 *}$, Ajay Tehare ${ }^{1}$, Chintan Dholakia1, Padmaja Sudhakar², Sameer \\ Agarwal $^{3 *}$ and Kumar K. Singh ${ }^{1}$
}

${ }^{1}$ Cadila Healthcare Limited, API Division, Sarkhej-Bavla N.H. No 8 A, Changodar, Ahmedabad- 382 210, India

${ }^{2}$ Department of Chemistry, Faculty of Science, M. S. University of Baroda, Baroda - 390 002, India

${ }^{3} Z y d u s$ Research Centre, Cadila Healthcare Ltd. Sarkhej-Bavla N.H. No 8 A, Moraiya, Ahmedabad- 382 210, India

An accurate, fast, precise and economic gradient reverse phase high performance liquid chromatographic (RP-HPLC) method was developed for quantitative determination of process and degradation related impurities in the solid dispersion of dasatinib drug substance. The optimum separation was achieved by Sunniest C18, $250 \times 4.6 \mathrm{~mm}, 5 \mu \mathrm{m}$ column at $35^{\circ} \mathrm{C}$. The mobile phase A was $20 \mathrm{mM}$ ammonium acetate buffer ( $\mathrm{pH} 5.0)$ and mobile phase $\mathrm{B}$ was composed of methanol:buffer:acetonitrile $(90: 5: 5)(\%, v / v / v)$; the chromatographic analysis was performed with gradient condition detecting the related substances at wavelength $310 \mathrm{~nm}$ at flow rate of $1.2 \mathrm{~mL} / \mathrm{min}$. The resolution for dasatinib and six related components was found to be greater than 2.0 for any pair of impurities. The stability indicating nature of the method was demonstrated by performing force degradation studies. Significant degradation was observed when the solid dispersion of dasatinib was subjected to oxidation, thermal and photo degradation, while the drug substance was stable in acid and alkali degradation. Relative standard deviation obtained for the system precision and method precision studies was less than $5 \%$. The accuracy of the method was demonstrated by performing recovery studies through spiking studies. The developed method was validated for linearity, specificity, accuracy, precision, limit of detection, limit of quantitation and robustness studies; it can be used in quality control for commercialization of solid dispersion of dasatinib drug substances and performing stability studies.

Keywords: Dasatinib, chromatographic method, stress testing, method validation.

\section{INTRODUCTION}

Dasatinib is an inhibitor of multiple tyrosine kinases, inhibiting the growth of chronic myeloid leukemia and acute lymphoblastic leukemia cell lines overexpressing BCR-ABL $[1,2]$. Dasatinib is an approved drug, sold under the brand name Sprycel, and is a chemotherapy medication used for the treatment of chronic myelogenous leukemia and acute lymphoblastic leukemia [3].

Stability testing is an integral part of the new drug development process because it provides quality of drug substances in different storage condition having variable temperature and humidity. As per the International Conference on Harmonization (ICH) Guideline Q1A(R2) [4], the shelf life of any drug substances is determined by stability studies. The quantification of impurities and dasatinib API is required to be determined using stability indicating chromatographic method, as suggested by the previously mentioned ICH guideline and United State Pharmacopoeia (USP) [5]. However, a few methods have been used for quantification of major tyrosine kinase inhibitors i.e. imatinib, dasatinib and nilotinib in human plasma [6-17]. 
Table I. Chemical structure of dasatinib and its impurities

\begin{tabular}{lll}
\hline $\begin{array}{c}\text { Impurity } \\
\text { particulars }\end{array}$ & Chemical structure & Source \\
Dasatinib & $\begin{array}{c}\text { IUPAC name } \\
\text { (2-chloro-6-methylphenyl)-2-((6-) } \\
\text { yl)-2-methylpyrimidin-4-yl) amino }) \\
\text { thiazole-5-carboxamide }\end{array}$ & Target API
\end{tabular}

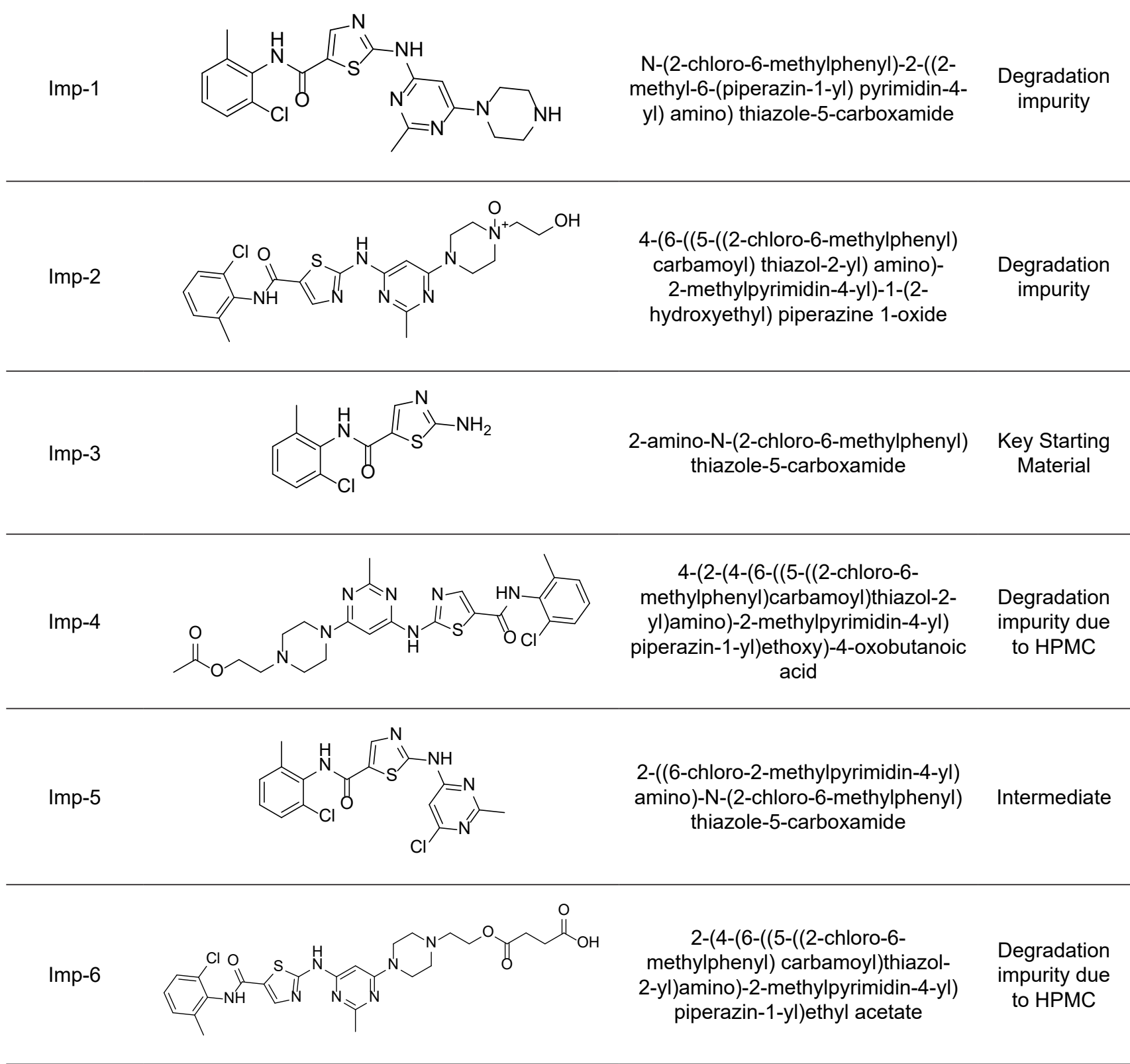

Several methods have been reported to determine only the process related impurities [18-20]. Moreover most of these methods are not validated and stability indicating. Thus, a novel robust method for the evaluation of all the process and degradation related impurities of solid dispersion of dasatinib 
drug substance is needed. In the present study we herein report the development and validation of a stability indicating chromatographic method for determination of process and degradation related impurities in solid dispersion of dasatinib drug substance by evaluating Response Factor (RF) values of each impurity as per validation of the $\mathrm{ICH}$ guideline. The developed method will be of high importance for the commercial production of dasatinib, an efficient oncological drug, with over $\$ 2000$ million market size.

Dasatinib is not present in any of the pharmacopeia till date. Since impurities in drug substance could cause toxic effects in the patients, thus the guidelines on impurities in new drug substance (Q3AR2) have been issued by ICH. Therefore, a stability-indicating RP-HPLC method was developed for the quantitative determination of dasatinib and its six impurities including process and degradation impurities i.e. Imp-1, 2, 3, 4, 5 and 6 (Table I). This method was successfully validated according to the $\mathrm{ICH}$ guidelines (validation of analytical procedures: test and methodology Q2). Dasatinib received marketing approval by the European Medicines Agency in November 2006 and was approved by the U.S. Food and Drug Administration in June 2006.

\section{MATERIAL AND METHODS}

\section{Samples and Reagents}

Dasatinib standards and samples were synthesized in API Division, Cadila Healthcare Ltd. (Ahmedabad, India), by a route of synthesis previously described [21]. HPLC grade acetonitrile and methanol, analytical grade ammonium acetate, acetic acid solution, and hydrogen peroxide solution (30\%) were purchased from Merck Specialities Pvt. Ltd. (Mumbai, India). High purity HPLC grade water was prepared by using Millipore Milli-Q Plus water purification system, Bradford, PA, USA.

\section{Preparation of Solid Dispersion of Dasatinib}

The solid dispersion of dasatinib was prepared by mixing dasatinib with hydroxypropyl methylcellulose (HPMC) in the ratio of $70: 30(\%, w / w)[21]$.

\section{HPLC Chromatographic Conditions}

The chromatographic experiments were performed on a Waters HPLC system with photodiode array detector. The detector wavelength was $310 \mathrm{~nm}$ and data processed using Empower 3 software, version builds 3471 . The column used for chromatography was Sunniest C18 $250 \times 4.6 \mathrm{~mm}, 5 \mu \mathrm{m}$ particle size. The optimum separation was achieved using a gradient mode. Mobile phase A was $20 \mathrm{mM}$ ammonium acetate $(\mathrm{pH} 5.0)$; mobile phase $B$ was mixtures of methanol, buffer and acetonitrile in a ratio of 90:5:5 $(\%, v / v / v)$. The flow rate was $1.2 \mathrm{~mL} / \mathrm{min}$. The gradient program is presented in Table-II. The column temperature was maintained at $35{ }^{\circ} \mathrm{C}$. The injection volume was $15 \mu \mathrm{L}$. A typical chromatogram of dasatinib and its six impurities is shown in Figure 1.

Table II. Gradient program of the HPLC method

\begin{tabular}{ccc}
\hline Time (min) & \% Mobile phase-A & \% Mobile phase-B \\
\hline 0.01 & 50 & 50 \\
23 & 45 & 55 \\
42 & 33 & 67 \\
50 & 10 & 90 \\
65 & 10 & 90 \\
68 & 50 & 50 \\
75 & 50 & 50 \\
\hline
\end{tabular}




\section{LC-MS Chromatographic Conditions}

An electrospray LC-MS system (Shimadzu Prominence HPLC coupled with Triple Quadrupole Mass Spectrometer LCMS-8040 with lab solution software, version 5.72, Japan) was used for identification of degradant impurities formed during the stress testing studies. Chromatography was performed on Sunniest C18 $250 \times 4.6$ mm, $5 \mu \mathrm{m}$ particle size column from ChromaNik Technologies Inc. (Made in Japan) using mobile phase consisting of mobile phase $\mathrm{A}(20 \mathrm{mM}$ ammonium acetate $\mathrm{pH} 5.0)$ and mobile phase $B$ (mixture of methanol, buffer and acetonitrile in a ratio of 90:5:5\%, v/v/v) at a flow rate of $1.2 \mathrm{~mL} / \mathrm{min}$. The LC gradient program has been applied as per Table II. The column temperature was maintained at $35^{\circ} \mathrm{C}$. Methanol:water:ACN in the ratio of 50:30:20 (\%, v/v/v) was used as a diluent. Injection volume was $15 \mu \mathrm{L}$. The analysis was carried out by using electrospray ionization mode (+ve and -ve). The capillary voltage at $3500 \mathrm{~V}$ and collision Energy $-35 \mathrm{~V}$. Desolvation temperature is $250{ }^{\circ} \mathrm{C}$ with nebulizing gas flow rate $180 \mathrm{~L} / \mathrm{h}$.

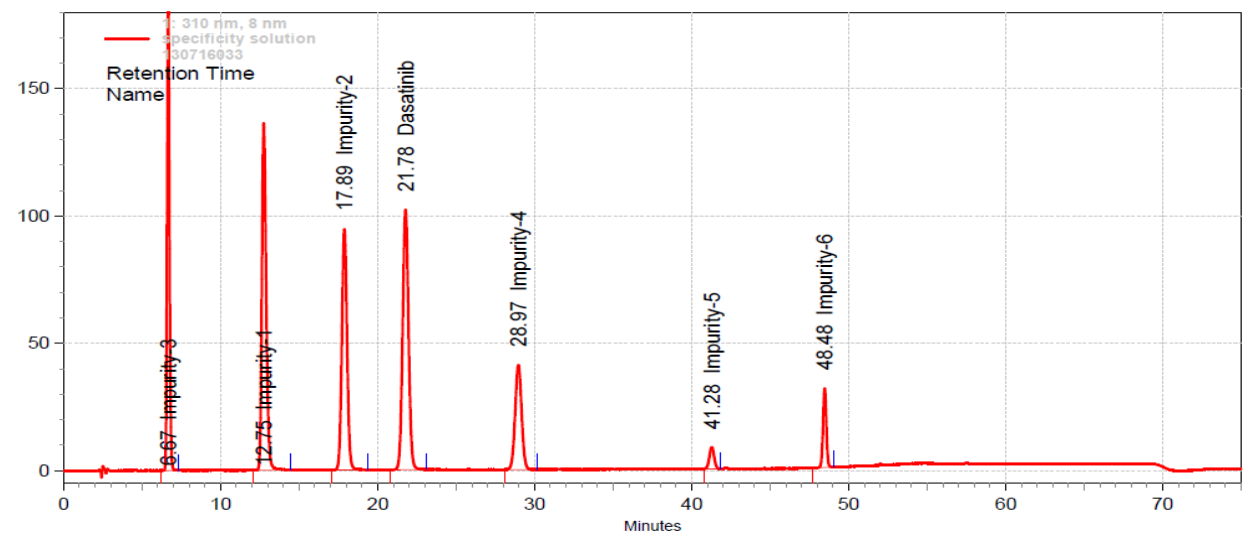

Figure 1.Typical chromatogram of dasatinib and its impurities.

\section{Preparation of Solutions}

Standard stock solutions for validation

Dasatinib stock solutions were prepared with a concentration of $1000 \mu \mathrm{g} \mathrm{mL}^{-1}$ for dasatinib in diluent, and a stock solution of impurities composite was prepared (a mixture of Imp-1, Imp-2, Imp-3, Imp-4 and Imp-6) at a concentration of $100 \mu \mathrm{g} \mathrm{mL}-1$. Imp-5 first stock was prepared in dimethyl sulfoxide (DMSO) and second stock was prepared $100 \mu \mathrm{g} \mathrm{mL}^{-1}$ in a diluent.

\section{Sample solution}

Dasatinib test solutions were prepared in a concentration of $1000 \mu \mathrm{g} \mathrm{mL}^{-1}$ in diluents, sonicated for 5 min to dissolve and were further analyzed by HPLC.

\section{Stress Degradation Studies}

Specificity can be performed by analysis of the sample spiked with process and degradation related impurities; no interference was observed at the retention time of interest analytes. Stress studies were performed at concentration of $1000 \mathrm{gg} \mathrm{mL}^{-1}$. Degradation was performed under stress condition of UV light $(254 \mathrm{~nm})$, heat $\left(105^{\circ} \mathrm{C}\right)$, acid $\left(1.0 \mathrm{~N} \mathrm{HCl}\right.$ at $\left.60{ }^{\circ} \mathrm{C}\right)$, base $\left(1.0 \mathrm{~N} \mathrm{NaOH}\right.$ at $\left.60{ }^{\circ} \mathrm{C}\right)$ and oxidation $(3 \%$ $\mathrm{H}_{2} \mathrm{O}_{2}$ at $25^{\circ} \mathrm{C}$ ) to evaluate the capability of the proposed method to separate dasatinib and all impurities including process and degradation products. For thermal and photo stress studies, the study period was $24 \mathrm{~h}$, whereas for acid hydrolysis approximately $1 \mathrm{~h}$; alkali hydrolysis $1 \mathrm{~h}$ and oxidation $1.5 \mathrm{~h}$. The purity of each peak was checked using PDA detector and the purity angle was found to be less than the purity threshold, directly demonstrated that peak is pure. Mass balance of each condition stressed samples 
was calculated by addition of \%content of dasatinib + \%known impurities + \%unknown impurities in \%, w/w.

\section{Method Validation Protocol}

The proposed method was validated for the determination of related substances in the solid dispersion of dasatinib by HPLC as per ICH guidelines [22]. The limit of detection (LOD) and limit of quantification (LOQ) for dasatinib and all six impurities were determined by signal to noise ratio of $3: 1$ and $10: 1$ respectively.

\section{RESULTS AND DISCUSSION Optimization of Chromatographic Method}

The main criteria for developing chromatographic method was that it must be stability indicating and easy to perform routine analysis in quality control laboratory. The first step for method development was the selection of wavelength. Analysis was performed by using diode array detector for selection of wavelength and to check homogeneity of peaks. The wavelength for analysis and quantification was selected based on UV spectrum of each impurity and analyte peak. Each peak is showing two UV maxima at about $220 \mathrm{~nm}$ and $320 \mathrm{~nm}$. $310 \mathrm{~nm}$ was selected as cross section wavelength of Impurity-3 and all other peaks. Reference overlay UV spectra has been provided in Figure 2. Thus detection wavelength was selected as $310 \mathrm{~nm}$ for related substance analysis. For a method development, spiked solution of dasatinib was used. Initially, experiments were based on the available literature, gradient method using Cosmosil BDS C18 column $(100 \mathrm{~mm} \times 4.6 \mathrm{~mm}, 3.5 \mu \mathrm{m}$ particle size $)$ with the mobile phase composed of triethyl amine buffer solution $\mathrm{pH} 6.5 \pm 0.05$ and solvent mixture (methanol, acetonitrile) in $50: 50(\%, \mathrm{v} / \mathrm{v})$ [11]. But in this method, Imp-2 and Imp-4 peaks were merged with dasatinib peak and Imp-6 peak was split. Hence, a gradient method trial was taken with $250 \mathrm{~mm} \times 4.6 \mathrm{~mm}, 5 \mu \mathrm{m}$ particle size column (Waters SunFire C18) and found that only Imp-4 peak was merged with dasatinib peak. As dasatinib has a pKa of 10.95 calculated by ACD Chem (SciFinder), to check the effect of $\mathrm{pH}$ on the resolution of impurities, methods were tried using buffers at different $\mathrm{pH}$ ranging from 4.5 to 7.5 without changing the ionization $\mathrm{pH}$ range of dasatinib i.e. $\mathrm{pKa} \pm 1.5$ [23]. For optimizing $\mathrm{pH}$ of the buffer, an HPLC column, Waters SunFire C18 (250 mm × $4.6 \mathrm{~mm}, 5 \mu \mathrm{m}$ particle size) was selected. Spike solution was injected with the above mentioned buffers having different $\mathrm{pH}$ as mobile phase $\mathrm{A}$ and mixture of methanol and acetonitrile in a ratio of $80: 20(\%, \mathrm{v} / \mathrm{v})$ as mobile phase $\mathrm{B}$ with gradient elution and it was observed that at $\mathrm{pH}$ below 4.5 and above 5.5, Imp-4 and dasatinib merged each other, but separation was achieved for all the six impurities and dasatinib at $\mathrm{pH} 5.0 \pm 0.5$. So finalized that method is sensitive to $\mathrm{pH}$. It was thus decided to use ammonium acetate-acetic acid buffer of $\mathrm{pH} 5.0$ as mobile phase A, and methanol:buffer:ACN in the ratio of 90:5:5 (\%, v/v/v) as mobile phase B with a gradient as per Table II, at a flow rate of $1.2 \mathrm{~mL} / \mathrm{min}$. In above trial Imp-5 and Imp-6 were eluted in the gradient hump. To overcome this, the gradient was increased to $75 \mathrm{~min}, 5 \%$ buffer was added to mobile phase B and Sunniest C18 (250 mm $\times 4.6 \mathrm{~mm}, 5 \mu \mathrm{m}$ particle size) column used for baseline smoothening at the retention time of Imp-5 and Imp-6. Using these chromatographic conditions, significant separation $(>2.0)$ for all the six impurities and dasatinib was achieved. The retention time of dasatinib was 20 min. The typical spike chromatogram of dasatinib and its impurities is presented in Figure 1. It was confirmed that no blank interference observed at the retention time of any of the impurities and dasatinib. LC-MS analysis of impurities was performed as per section "HPLC Chromatographic Conditions" as instrument condition. 


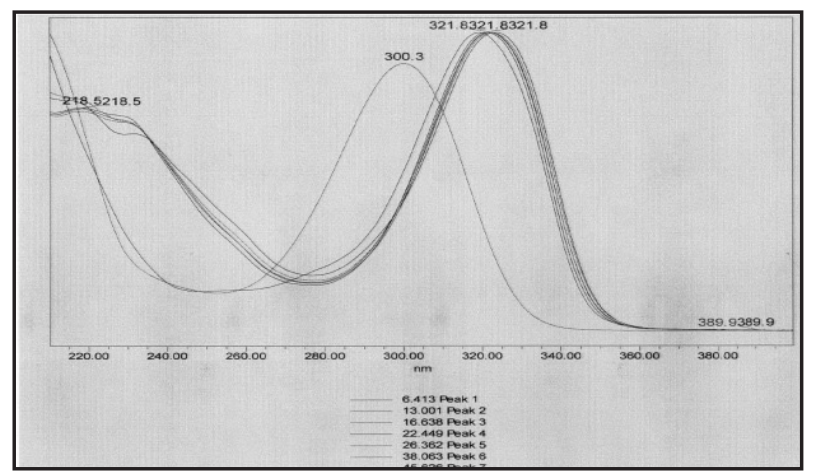

Figure 2. Reference overlay UV spectra of dasatinib and its impurities.

In the developed HPLC conditions, system suitability parameters like tailing factor, USP theoretical plates and USP resolution were evaluated for dasatinib and its six impurities (Figure 1). USP theoretical plates for all impurities was more than 5000, USP tailing factor for all the impurities was less than 1.5 and USP resolution between any pair of impurities were more than 2.0 (Table III).

Table III. System suitability parameters

\begin{tabular}{lcccccc}
\hline $\begin{array}{l}\text { Imp } \\
\text { particulars }\end{array}$ & RT (min) & RRT & $\begin{array}{c}\text { USP } \\
\text { resolution }\end{array}$ & $\begin{array}{c}\text { USP tailing } \\
\text { factor }\end{array}$ & $\begin{array}{c}\text { USP theoretical } \\
\text { plates }\end{array}$ & \%RSD \\
\hline Imp-3 & 6.67 & 0.30 & - & 1.10 & 7964 & 1.22 \\
Imp-1 & 12.75 & 0.58 & 15.37 & 1.23 & 10108 & 0.92 \\
Imp-2 & 17.89 & 0.82 & 9.30 & 1.04 & 13629 & 1.35 \\
Dasatinib & 21.78 & 1.00 & 6.00 & 1.04 & 15084 & 1.25 \\
Imp-4 & 28.97 & 1.33 & 9.88 & 1.01 & 23763 & 1.65 \\
Imp-5 & 41.28 & 1.90 & 18.35 & 1.02 & 79760 & 1.42 \\
Imp-6 & 48.48 & 2.23 & 14.80 & 0.98 & 239541 & 1.72 \\
\hline
\end{tabular}

\section{Method validation}

Precision

The precision of the method was determined by intermediate precision and method precision studies. In both the studies \%Relative Standard Deviation of peak areas for all the impurities were less than $5.0 \%$. These results demonstrate that the method is precise (Table IV).

\section{Limit of Detection and Limit of Quantitation}

LOD and LOQ for dasatinib and all six impurities were determined by signal to noise ratio of $3: 1$ and 10:1 respectively. LOD and LOQ values were reported in Table IV.

Method precision study was also conducted at the LOQ level and calculated the \%RSD for the areas of each Impurity. Accuracy at LOQ level was confirmed by injecting three different preparations of dasatinib spiked with impurities at $L O Q$ level and calculated \%, w/w recoveries of each impurity. 
Table IV. Regression, precision, LOQ and LOD data

\begin{tabular}{lcccccccc}
\hline Imp Particulars & $\begin{array}{c}\text { LOD } \\
\left(\mu \mathrm{mL}^{-1}\right)\end{array}$ & $\begin{array}{c}\text { LOQ } \\
\left(\mu \mathrm{g} \mathrm{mL}^{-1}\right)\end{array}$ & \multicolumn{2}{c}{ Regression equation $(\mathbf{y})$} & $\begin{array}{c}\text { Correlation } \\
\text { coefficient }\end{array}$ & $\begin{array}{c}\mathbf{R}^{2} \\
\text { value }\end{array}$ & $\begin{array}{c}\text { Method } \\
\text { Precision } \\
(\% \text { InSD) }\end{array}$ & $\begin{array}{c}\text { Intermediate } \\
\text { precision } \\
(\% R S D)\end{array}$ \\
\hline Imp-3 & 0.06 & 0.21 & 39934 & 703 & 1.000 & 0.9997 & 1.49 & 1.20 \\
Imp-1 & 0.07 & 0.23 & 47555 & -250 & 1.000 & 0.9994 & 1.91 & 1.10 \\
Imp-2 & 0.04 & 0.15 & 38955 & 1195 & 1.000 & 0.9990 & 1.64 & 0.80 \\
Dasatinib & 0.05 & 0.18 & 50006 & 2332 & 0.999 & 0.9980 & N.A. & N.A. \\
Imp-4 & 0.07 & 0.21 & 32346 & 1332 & 0.999 & 0.9980 & 3.27 & 1.52 \\
Imp-5 & 0.08 & 0.25 & 35119 & 3659 & 1.000 & 0.9991 & 1.43 & 1.10 \\
Imp-6 & 0.15 & 0.30 & 20198 & 571 & 0.998 & 0.9979 & 3.63 & 2.40 \\
\hline
\end{tabular}

\section{Accuracy}

The accuracy of the method was determined by spiking of all impurities at four different level i.e. LOQ level, $50 \%$ level, $100 \%$ level and $150 \%$ level of specification limit $(0.15 \%)$. Recovery for all six impurities was found within the range of 80 to $120 \%$. Recovery study and method precision results are reported in Table V.

Table V. Results of accuracy and method precision

\begin{tabular}{|c|c|c|c|c|c|c|}
\hline Accuracy Level & Imp-1 & Imp-2 & Imp-3 & Imp-4 & Imp-5 & Imp-6 \\
\hline \multicolumn{7}{|l|}{ LOQ recovery } \\
\hline LOQ R-1 & 92.2 & 114.1 & 106.2 & 105.2 & 109.6 & 95.8 \\
\hline LOQ R-2 & 101.3 & 106.8 & 94.5 & 112.0 & 109.8 & 102.1 \\
\hline LOQ R-3 & 82.7 & 99.5 & 95.6 & 85.5 & 106.2 & 95.2 \\
\hline \multicolumn{7}{|l|}{$50 \%$ level recovery } \\
\hline $50 \%$ Level R-1 & 104.4 & 110.3 & 104.9 & 107.3 & 106.1 & 94.3 \\
\hline $50 \%$ Level R-2 & 98.1 & 105.0 & 97.9 & 110.2 & 108.7 & 96.1 \\
\hline 50\% Level R-3 & 95.6 & 104.2 & 102.1 & 108.4 & 98.4 & 97.3 \\
\hline \multicolumn{7}{|c|}{$100 \%$ level recovery (method precision) } \\
\hline Spike solution-1 & 102.3 & 105.5 & 100.0 & 100.8 & 97.2 & 97.6 \\
\hline Spike solution-2 & 104.6 & 105.1 & 104.1 & 99.6 & 101.0 & 96.4 \\
\hline Spike solution-3 & 105.0 & 105.0 & 101.1 & 100.9 & 100.8 & 93.9 \\
\hline Spike solution-4 & 101.2 & 101.6 & 103.0 & 103.0 & 100.2 & 104.0 \\
\hline Spike solution-5 & 104.2 & 105.5 & 103.3 & 100.3 & 99.8 & 96.8 \\
\hline Spike solution-6 & 105.6 & 105.6 & 102.1 & 108.6 & 100.6 & 95.2 \\
\hline \multicolumn{7}{|l|}{$150 \%$ level recovery } \\
\hline $150 \%$ level R-1 & 109.6 & 108.5 & 106.8 & 109.8 & 103.6 & 107.8 \\
\hline $150 \%$ level R-2 & 110.1 & 109.7 & 106.7 & 106.6 & 104.1 & 85.9 \\
\hline $150 \%$ level R-3 & 108.4 & 107.8 & 105.0 & 103.6 & 102.7 & 108.5 \\
\hline
\end{tabular}

Linearity of method was calculated at seven levels ranging from LOQ to $150 \%$ (i.e. $0.30,0.45,0.75$, 
$1.20,1.50,1.80$ and $2.25 \mu \mathrm{g} \mathrm{mL}^{-1}$ ) to the specification level of $0.15 \%$, while for drug substance calibration curve was obtained for dasatinib in the concentrations ranging from LOQ to $150 \%$ (i.e. $0.20,0.30,0.50$, $0.80,1.00,1.20$ and $1.50 \mu \mathrm{g} / \mathrm{mL}$ ) to the specification level of $0.10 \%$. The correlation coefficient was found more than 0.990 for all the impurities. The slope, correlation coefficient and $y$-intercept values have been reported in Table IV, which specified linear method.

\section{Robustness}

We have performed robustness study as per $\mathrm{ICH}$ guideline of analytical method validation, which covers most of the critical variables of analytical method. For demonstrate the robustness of developed method spiked sample was analyzed by altered chromatographic conditions (flow rate, $\mathrm{pH}$ and column temperature). No significant difference in quantification and resolution which specify that the developed method is robust. Results of robustness study were reported in Table VI.

Table VI. Results of robustness study

\begin{tabular}{cccccccc}
\hline \multirow{2}{*}{ Parameter/variation } & \multicolumn{7}{c}{ USP resolution } \\
\cline { 2 - 8 } & Imp-3 & Imp-1 & Imp-2 & Dasatinib & Imp-4 & Imp-5 & Imp-6 \\
\hline As such conditions & 5.6 & 15.37 & 9.30 & 6.00 & 9.88 & 18.35 & 14.80 \\
\hline Flow rate $(\mathrm{mL} / \mathrm{min})$ & & & & & & & \\
\hline a. 1.15 & 5.7 & 15.8 & 9.8 & 6.2 & 10.1 & 18.9 & 15.2 \\
b. 1.25 & 5.4 & 15.2 & 9.1 & 5.8 & 9.4 & 18.0 & 14.5 \\
\hline Temperature $\left({ }^{\circ} \mathrm{C}\right)$ & & & & & & & 18.7 \\
\hline a. 32 & 5.6 & 15.7 & 9.8 & 6.3 & 10.0 & 15.0 \\
b. 38 & 5.3 & 15.1 & 9.0 & 5.6 & 9.2 & 17.9 & 14.8 \\
\hline Buffer pH & & & & & & & \\
\hline a. 4.9 & 5.2 & 15.3 & 9.3 & 5.9 & 10.8 & 18.0 & 14.7 \\
b. 5.1 & 5.5 & 15.3 & 9.8 & 6.0 & 7.0 & 18.1 & 15.2 \\
\hline
\end{tabular}

\section{Specificity and stress testing studies}

For specificity study, each Imp-1 to Imp-6, HPMC and dasatinib were injected separately. Spiked sample was also injected and from diode array detector purity plots extracted for each impurities in the spiked sample. $1000 \mu \mathrm{g} \mathrm{mL}^{-1}$ dasatinib solution was injected for each stress testing studies. Degradation was not observed when the solid dispersion of dasatinib was subjected to alkali degradation ( $1 \mathrm{~N}$ $\mathrm{NaOH}$ heat at $60{ }^{\circ} \mathrm{C}$ for $1 \mathrm{~h}$ ) and acid degradation $\left(1 \mathrm{~N} \mathrm{HCl}\right.$ heat at $60{ }^{\circ} \mathrm{C}$ for $1 \mathrm{~h}$ ) conditions. $15.0 \%$ degradation was observed when the drug was subjected to oxidation ( $3 \% \mathrm{H}_{2} \mathrm{O}_{2}$ for $1.5 \mathrm{~h}$ ) leading to the formation of Imp- 2, thermal degradation ( $105^{\circ} \mathrm{C}$ approximately $24 \mathrm{~h}$ ) leading to the formation of Imp4 and Imp-6, and UV degradation (254 nm for $24 \mathrm{~h}$ ) leading to the formation of Imp-1 and Imp-6. The degradation products that were formed during the stress studies were confirmed by co-injecting with the standard solution with stressed samples. Results from stress testing studies were reported in Table VII. An assay was calculated against dasatinib standard solution. The mass balance was calculated for each condition stressed samples and was found to be in the range of $95-105 \%$ which confirms that the developed method was stability-indicating. Depending on the chemistry and structure of molecule it may undergo degradation in specific strength of acid, base or peroxide at specific temperature only, hence only some specific conditions influence the degradation of drug substance.

Peak purity was checked in the degraded sample and calculate purity angle and purity threshold for the known impurity are reported in Table VIII. This table shows that purity angle is less than purity threshold for known impurity peak formed due to degradation. 
Table VII. Summary of stress testing results

\begin{tabular}{|c|c|c|c|c|c|c|}
\hline $\begin{array}{l}\text { Degradation } \\
\text { condition }\end{array}$ & Time & Temp. & $\begin{array}{l}\text { Assay } \\
(\%, w / w)\end{array}$ & $\begin{array}{l}\text { RS by HPLC } \\
\% \text { degradation }\end{array}$ & $\begin{array}{l}\text { Mass balance } \\
\text { ( } \% \text { assay }+\% \\
\text { deg. products) }\end{array}$ & Remarks/observation \\
\hline $\begin{array}{l}\text { A control sample } \\
\text { (untreated) }\end{array}$ & - & - & 100.6 & 0.27 & 100.8 & NA \\
\hline $\begin{array}{l}\mathrm{HCl}, 1.0 \mathrm{~N} \text { (acid } \\
\text { degradation) }\end{array}$ & $1 \mathrm{~h}$ & $60^{\circ} \mathrm{C}$ & 100.8 & 0.22 & 101.0 & $\begin{array}{c}\text { No significant } \\
\text { degradation observed }\end{array}$ \\
\hline $\begin{array}{l}\mathrm{NaOH}, 1.0 \mathrm{~N} \text { (base } \\
\text { degradation) }\end{array}$ & $1 \mathrm{~h}$ & $60^{\circ} \mathrm{C}$ & 100.9 & 0.25 & 101.1 & $\begin{array}{c}\text { No significant } \\
\text { degradation observed }\end{array}$ \\
\hline $\begin{array}{l}\text { Oxidation by } 3.0 \% \\
\mathrm{H}_{2} \mathrm{O}_{2}\end{array}$ & $1.5 \mathrm{~h}$ & $25^{\circ} \mathrm{C}$ & 84.7 & 12.26 & 96.9 & Imp-2 was formed \\
\hline Thermally treated & $24 \mathrm{~h}$ & $105^{\circ} \mathrm{C}$ & 98.1 & 0.68 & 98.79 & $\begin{array}{c}\text { Imp-4 and Imp-6 } \\
\text { impurities were formed }\end{array}$ \\
\hline UV treated (254 nm) & $24 \mathrm{~h}$ & $25^{\circ} \mathrm{C}$ & 99.7 & 0.64 & 100.4 & $\begin{array}{c}\text { Imp-1 and Imp-6 } \\
\text { impurities were formed }\end{array}$ \\
\hline
\end{tabular}

Table VIII. Peak purity results

\begin{tabular}{lcccccccccc}
\hline \multirow{2}{*}{$\begin{array}{l}\text { Degradation } \\
\text { condition }\end{array}$} & \multicolumn{2}{c}{ Imp-1 } & \multicolumn{2}{c}{ Imp-2 } & \multicolumn{2}{c}{ Imp-4 } & \multicolumn{2}{c}{ Imp-6 } & \multicolumn{2}{c}{ Dasatinib } \\
\cline { 2 - 11 } & $\begin{array}{l}\text { Purity } \\
\text { angle }\end{array}$ & $\begin{array}{c}\text { Purity } \\
\text { threshold }\end{array}$ & $\begin{array}{c}\text { Purity } \\
\text { angle }\end{array}$ & $\begin{array}{c}\text { Purity } \\
\text { threshold }\end{array}$ & $\begin{array}{c}\text { Purity } \\
\text { angle }\end{array}$ & $\begin{array}{c}\text { Purity } \\
\text { threshold }\end{array}$ & $\begin{array}{c}\text { Purity } \\
\text { angle }\end{array}$ & $\begin{array}{c}\text { Purity } \\
\text { threshold }\end{array}$ & $\begin{array}{c}\text { Purity } \\
\text { angle }\end{array}$ & $\begin{array}{c}\text { Purity } \\
\text { threshold }\end{array}$ \\
\hline Oxidation & - & - & 0.079 & 0.219 & - & - & - & - & 0.291 & 0.522 \\
Thermal & - & - & - & - & 0.263 & 0.347 & 0.524 & 0.643 & 0.631 & 1.104 \\
UV Treated & 0.259 & 1.144 & - & - & - & - & 0.692 & 1.647 & 0.417 & 1.001 \\
\hline
\end{tabular}

\section{Relative Response Factor}

The slope of each impuritiy and dasatinib was calculated from seven levels linearity. Relative response factor was calculated by a slope of dasatinib divided by the slope of respective impurity. Relative Response Factor for all six impurities has been reported in Table IX, which is not more than 3.0 for any impurity. Thus developed method was highly efficient, as quantification has been done by a diluted standard solution of dasatinib and no need to inject all impurity standards. Quantification of impurities was done by multiplying response factor of respective impurity.

Table IX. Relative Response Factor

\begin{tabular}{cc}
\hline Impurity Particulars & Response Factor \\
\hline Imp-3 & 1.25 \\
Imp-1 & 1.05 \\
Imp-2 & 1.28 \\
Dasatinib & 1.00 \\
Imp-4 & 1.55 \\
Imp-5 & 1.42 \\
Imp-6 & 2.48 \\
\hline
\end{tabular}




\section{CONCLUSION}

An accurate, selective and sensitive gradient RP-HPLC method has been developed and validated as per regulatory guideline for the determination of process and degradation related impurities for the oncology drug, dasatinib. In addition, the developed method is cost effective as there is no need to inject expensive impurities standard solution during method validation. Taken together, developed RPHPLC method demonstrated precise, economical and commercially viable quantitative determination of dasatinib impurities which will also be useful for industrial scale manufacturing.

\section{Acknowledgment}

The authors would like to acknowledge the management of Cadila Healthcare Ltd. for support and encouragement. ZRC Communication Nº 565.

\section{Compliance with ethical standards}

The authors declare that they have no conflict of interest.

Manuscript received: 08/08/18; revised manuscript received: 10/31/18; revised manuscript for the $2^{\text {nd }}$ time received: 12/31/18; manuscript accepted: 01/09/19; published online: 01/28/19.

\section{REFERENCES}

1. Ali, M. Mol. Diagn. Ther., 2016, 20, pp 315-333. doi: 10.1007/s40291-016-0208-1

2. Miura, M. Bio. Pharm. Bull., 2015, 38, pp 645-654. doi: 10.1248/bpb.b15-00103

3. Drug Bank: Dasatinib (DB01254).

4. International Conference on Harmonization. ICH Q1A(R2). Stability Testing of New Drug Substances and Products, 2003.

5. The United States Pharmacopoeia 39th ed., US Pharmacopoeia Convention, MD. 2017.

6. Zeng, J.; Cai, H. L.; Jiang, Z. P.; Wang, Q.; Zhu, Y.; Xu, P.; Zhao, X. L. J. Pharm. Anal., 2017, 7, pp 374-380. doi: 10.1016/j.jpha.2017.07.009

7. Pirro, E.; De Francia, S.; De Martino, F.; Fava, C.; Ulisciani, S.; Cambrin, G.; Racca, S.; Saglio, G.; Di Carlo, F. J. Chromatogr. Sci., 2011, 49 (10), pp 753-757. doi: 10.1093/chrsci/49.10.753

8. Gonzalez, A. G.; Taraba, L.; Hranicek, J.; Kozlik, P.; Coufal, P. J. Sep. Sci., 2017, 40, pp 400-406. doi: 10.1002/jssc.201600950

9. Prinesh, P.; Gananadhamu, S.; Veeraraghavan, S.; Rambabu, A.; Kanthi Kiran, V. S.; Swaroop Kumar, V. V. S. Anal. Methods., 2014, 6, pp 433-439. doi: 10.1039/C3AY41287C

10. D’Avolio, A.; Simiele, M.; De Francia, S.; Ariaudo, A.; Baietto, L.; Cusato, J.; Fava, C.; Saglio, G.; Di Carlo, F.; Di Perri, G. J. Pharm. Biomed. Anal., 2012, 59, pp 109-116. doi: 10.1016/j.jpba.2011.10.003

11. Lankheet, N.; Hillebrand, M.; Rosing, H.; Schellens, J.; Beijnen, J.; Huitema, A. Biomed. Chromatogr., 2013, 27 (4), pp 466-476. doi: 10.1002/bmc.2814

12. Hesham, K.; Motiur, R. A. F. M.; Mohammed, K. Dasatinib. In: Brittain, H. G. (Ed.). Profiles of Drug Substances, Excipients and Related Methodology. Elsevier, San Diego, CA, 2014, 39, Chapter 4, pp 205-237.

13. De Francia, S.; D’Avolio, A.; De Martino, F.; Pirro, E.; Baietto, L.; Siccardi, M.; Simiele, M.; Racca, S.; Saglio, G.; Di Carlo, F.; Di Perri, G. J. Chromatogr. B Analyt. Technol. Biomed. Life Sci., 2009, 877, pp 1721-1726. doi: 10.1016/j.jchromb.2009.04.028

14. Andriamanana, I.; Gana, I.; Duretz, B.; Hulin, A. J. Chromatogr. B Analyt. Technol. Biomed. Life Sci., 2013, 926, pp 83-91. doi: 10.1016/j.jchromb.2013.01.037

15. Catarina, J.; Victor, D.; J. Electroanal. Chem., 2015, 752, pp 47-53.

doi: 10.1016/j.jelechem.2015.06.006 
16. Couchman, L.; Birch, M.; Ireland, R.; Corrigan, A.; Wickramasinghe, S.; Josephs, D.; Spicer, J.; Flanagan, R. Anal. Bioanal. Chem., 2012, 403, pp 1685-1695. doi: 10.1007/s00216-012-5970-2

17. Gotze, L.; Hegele, A.; Metzelder, S.; Renz, H.; Nockher, W. Clin. Chim. Acta., 2012, 413, pp 143149. doi: 10.1016/j.cca.2011.09.012

18. Balaji, N.; Sultana, S. Int. J. Pharm. Sci., 2016, 8 (10), pp 209-216. doi: 10.22159/ijpps.2016v8i10.14020

19. Sunil, L.; Sajid, S.; Dhramveer Singh, S.; Nishikumar, N.; Radhiah Che, R.; Nurul Syazwani, N.; Mohd Zulfadli, M. Int. J. Chem. Sci., 2017, 15 (4) p 177.

20. Sunil, L.; Dhramveer Singh, S.; Nishikumar, N.; Radhiah Che, R.; Sajid Syed, S. Int. J. Sci. and Res., 2017, 6 (11), pp 51-58. doi: 10.21275/ART20177411

21. Dwivedi, S. P.; Singh, K. K.; Singh, N. A.; Patil, A. U.S. 9,249,134 B2, 2016, Cadila Healthcare Itd, Ahmedabad, India.

22. International Conference on Harmonization. ICH Q2 (R1) Validation of Analytical Procedures: Text and Methodology, 2005.

23. Snyder, L.; Kirkland, J.; Glajch, J. Practical HPLC Method Development. $2^{\text {nd }}$ ed., John Wiley and Sons, New York, 1997, pp 184-185. 